\title{
Glycemic control in critically ill surgical patients: risks and benefits
}

This article was published in the following Dove Press journal:

Open Access Surgery

19 March 2015

Number of times this article has been viewed

\section{Kaushik Mukherjee' \\ Vance L Albaugh ${ }^{2}$ \\ Justin E Richards ${ }^{3}$ Kelli A Rumbaugh ${ }^{4}$ \\ Addison K May'}

'Division of Trauma and Surgical Critical Care, ${ }^{2}$ Division of General Surgery, ${ }^{3}$ Department of Anesthesiology, ${ }^{4}$ Department of Pharmaceutical Services, Vanderbilt University Medical Center, Nashville, TN, USA
Correspondence: Addison K May Division of Trauma and Surgical Critical Care, Vanderbilt University Medical Center, 404 Medical Arts Building, I2I I Medical Center Drive, Nashville, TN 37212 , USA

$\mathrm{Tel}+\mathrm{I} 6159367188$

Fax +I 6159360185

Email addison.may@vanderbilt.edu
Abstract: Glucose metabolism in humans is exceedingly complex. At baseline, it is controlled by elaborate signaling mechanisms, and these mechanisms are profoundly altered by the surge of catecholamines and cytokines associated with acute postsurgical and post-traumatic stress. These alterations in signaling mechanisms result in hyperglycemia; although this hyperglycemia can start very rapidly after the traumatic or surgical insult, it can persist during the entire period of critical illness and even afterward. Numerous randomized clinical trials have been conducted to determine if hyperglycemia is associated with increased mortality in surgical patients. These studies have had different conclusions that are difficult to interpret in light of differences in study methodology, but there is certainly ample evidence that inadequately controlled hyperglycemia causes harm due to increased infectious morbidity, and possibly increased mortality. As we have become more proficient in controlling hyperglycemia, the concept of insulin resistance, determined as the amount of insulin required to achieve hyperglycemia, has come to the fore. Insulin resistance is not a static concept, and may change before significant events such as infection. Patients with elevated and persistent insulin resistance have been demonstrated to suffer increased infectious morbidity and mortality, albeit in nonrandomized studies. Along with insulin resistance, the concept of glycemic variability, the amount of variation in serum blood glucose over time, has also become relevant; increased variability has been associated with hypoglycemia and mortality. Both of these risks can result from aggressive insulin therapy, and glycemic control protocols must be appropriately planned and implemented to avoid hypoglycemia and excessive externally induced variability. Computer-assisted protocols may be of significant benefit in optimizing glycemic control. The most recent recommendations available are to keep serum blood glucose levels below $150 \mathrm{mg} / \mathrm{dL}$ and to avoid hypoglycemia.

Keywords: insulin resistance, hypoglycemia, insulin signaling, hyperglycemia, critical illness, glycemic variability

\section{Introduction}

The maintenance of serum blood glucose (BG) in humans is an exceedingly complex endeavor involving multiple organ systems including the liver, pancreas, small intestine, and skeletal muscle. Maintaining serum glucose levels is critical as glucose is the primary energy source for multiple tissues, most importantly those of the central nervous system. While relatively short periods of hypoglycemia may expose a critically ill patient to an increased risk of mortality, severe hyperglycemia may expose patients to increased risk of mortality ${ }^{1}$ and increased risk of surgical site infection (SSI) ${ }^{2-7}$ Following periods of traumatic and surgical stress, changes induced in the insulin signaling pathways contribute to decreases in insulin sensitivity that lead to hyperglycemia, even in nondiabetic patients. Hyperglycemia in these patients contributes to the risk 
of adverse outcomes. Control of severe hyperglycemia has been associated with improved outcomes in critically ill and postsurgical patients, although the benefit may be negated if the risk of hypoglycemia is high.

Over the past 15 years, the pendulum of glycemic control has switched from permissive hyperglycemia, tolerating levels much greater than $200 \mathrm{mg} / \mathrm{dL}$, to aggressive BG control with a target range of $80-110 \mathrm{mg} / \mathrm{dL}$, and subsequently back to a midrange target, as literature has demonstrated the potential harm induced by hypoglycemia during aggressive efforts to control glucose levels. ${ }^{8-10}$ To enable a full understanding of the physiologic changes induced by stress and the risks and potential benefits of efforts to maintain glucose levels in the critical ill and postsurgical patient, the changes in basic insulin signaling, evidence supporting the range of control, and system support to optimize control will be reviewed.

\section{Normal insulin signaling}

Along with the pancreas and intestinal tract, the skeletal muscle, adipose tissue, and liver form an elegant physiologic model of glucose homeostasis. In the postabsorptive state, the liver maintains BG concentration through gluconeogenesis for glucose-dependent tissues. During the absorptive state, insulin-independent glucose uptake by the pancreatic beta cells leads to glucose-stimulated insulin secretion into the portal circulation, where it first acts through the insulin receptor (IR) to decrease hepatic glucose output. The remaining insulin acts in the skeletal muscle and adipose tissue to increase glucose clearance from the circulation. As meal-derived glucose is taken into the peripheral tissues or cleared by the liver for storage as glycogen, the stimulus for insulin secretion diminishes.

The IR is a receptor tyrosine kinase and exists as a dimer of either of two splice variants (IR-A and IR-B) that may have differential downstream effects. ${ }^{11-13}$ Upon binding insulin or insulin-like growth factor (IGF)-1 or IGF-2, the receptor undergoes a conformational change leading to autophosphorylation of intracellular tyrosine residues, allowing for the binding of other signal transduction molecules such as Src homology 2 (SH2) domain-containing proteins. ${ }^{14,15}$ Similar to other transmembrane signaling receptors, the IR contains other binding domains (eg, pleckstrin homology) that cluster signaling proteins at the receptor and activate or deactivate effector molecules, including kinases, phosphatases, and G-proteins (Figure 1). ${ }^{16-18}$

The most important of these are the IR substrate (IRS) proteins, also containing SH2 domains. ${ }^{19-21}$ IRS-1 is viewed as the most important for glucose metabolism and IRS-2 is primarily involved with lipid metabolism, but with overlap in function due to cross talk between downstream effectors. $^{22-25}$ The functions of IRS-3 and IRS-4 are still being elucidated. ${ }^{26-32}$ IRS proteins propagate the insulin signal via phosphorylation on tyrosine residues, while serine and threonine phosphorylation sites on IRS proteins can terminate or preclude the insulin signal. ${ }^{11,33-35}$

A number of other receptors and signaling pathways can modulate the insulin signal, ${ }^{2-7}$ including the phosphoinositol system (PI3K), atypical protein kinase C (PKC), Akt, mTOR, ${ }^{36,37}$ ribosomal protein S6 kinase-1 (S6K1), and ERK1/2 ${ }^{11-13}$ pathways. One of the most important from a surgical perspective is the tumor necrosis factor (TNF)- $\alpha$ inflammatory signaling pathway with downstream activation of JNK and interleukin (IL)-6. ${ }^{14,15}$ Well-described mediators of inflammation (eg, nuclear factor kappa B and IKK) and proinflammatory cytokines (eg, TNF- $\alpha$, IL-6) have been shown to inhibit cellular transmission of the insulin signal, contributing to insulin resistance. ${ }^{16-18}$ Suppressors of cytokine signaling (SOCS) proteins cause ubiquitin-mediated degradation of IRS proteins, also downregulating the insulin signal. ${ }^{19-21}$ Knockout of SOCS proteins or proinflammatory cytokines (ie, IL-6) is associated with preserved insulin signaling. ${ }^{22-25}$ Similarly, a chronic state of inflammation may underlie the development of diabetes and obesity and drive worsening insulin resistance. ${ }^{26-32}$

There are a number of other tissue- and cell-specific signaling pathways downstream of the IR that modulate the activity of downstream targets. ${ }^{11,33-35}$ This tissue specificity leads to not only clearance of glucose from the plasma via the membrane trafficking of GLUT4, ${ }^{38,39}$ but also to other actions of insulin, including effects on protein synthesis ${ }^{40}$ and proteolysis, ${ }^{41,42}$ cellular proliferation and cancer, ${ }^{43}$ appetite and centrally mediated control of glucose homeostasis, ${ }^{44,45}$ and endothelial dysfunction/hypertension. ${ }^{46}$ While these mechanisms work well in nondiabetic patients at baseline, they can become profoundly altered with the introduction of acute stress in the setting of critical illness and injury.

\section{Insulin signaling following acute stress}

The response to severe stress involves activation of the neuroendocrine system with a resulting release of multiple hormones including cortisol, norepinephrine, epinephrine, glucagon, and growth hormone ${ }^{47}$ that contribute to systemic inflammation and increase hepatic gluconeogenesis. A total of $30 \%-40 \%$ of critically ill patients suffer from 




Figure I Insulin receptor signaling and downstream pathways.

Notes: An insulin molecule binds to the transmembrane IR, actually a dimer of IR-A or IR-B subunits. This in turn binds the SH2 domain of IRS family proteins, resulting in the activation of numerous downstream pathways. Proinflammatory proteins, including TNF- $\alpha$, JNK, IL-6, NF- KB, and IKK, inhibit these downstream pathways, thus blunting the response to insulin. SOCS proteins degrade IRS proteins via a ubiquitin-dependent mechanism, thus inhibiting the root of the insulin response.

Abbreviations: IR, insulin receptor; SH2, Src homology 2; SOCS, suppressors of cytokine signaling; IRS, insulin receptor substrate; PI3K, phosphoinositol system; PKC, protein kinase C; S6KI, S6 kinase I; TNF, tumor necrosis factor; IL, interleukin; NF-KB, nuclear factor kappa B.

stress-induced hyperglycemia as a result, although some proportion of these patients may have occult diabetes mellitus (DM). ${ }^{48-51}$ Moderate hyperglycemia may be protective in the stressed setting to ensure an adequate glucose supply for the brain and the immune system. ${ }^{52,53}$ The pancreas increases insulin secretion in response; although this is inadequate to create euglycemia, it upregulates the GLUT transporters ${ }^{47}$ allowing for rapid intracellular glucose utilization (Figure 2). ${ }^{54}$

Hypoxia-inducible factors respond to stress-induced hypoxia, upregulate GLUT expression, erythropoieitin, and VEGF, and shift away from aerobic to anaerobic metabolism. ${ }^{47}$ Sepsis, another common trigger for critical illness, inhibits glycogen synthesis; as a result, a large supply of glucose is available for cellular uptake, largely by the immune cells combating the systemic infection. ${ }^{47}$ Although hyperglycemia provides glucose for immune cells, it also reduces the effectiveness of monocytes, macrophages, and neutrophils via the inhibition of cytokine secretion and myeloperoxidase activity. ${ }^{52}$ As in hypoxia, metabolism is shifted toward anaerobic modalities.

The durability of stress-induced hyperglycemia is surprising. Frequently, critically ill patients increase their insulin resistance over days to weeks; changes in hyperglycemia and insulin resistance may be indicative of impending infection. ${ }^{55}$ Changes in gene expression that occur as a result of changes in hormone levels and the activation of cytokines may result in long-term changes in glucose metabolism. ${ }^{56}$ It remains to be seen what the definitive impact of all these changes in cytokine and gene expression are on mortality, although this particular question is one that has been the subject of numerous studies and clinical trials.

\section{Hyperglycemia and mortality in surgical patients}

Admission hyperglycemia is a common finding in the critically ill and injured population. Although in some cases this is due to occult DM, the vast majority of hyperglycemic trauma patients are nondiabetic; ${ }^{49} 78 \%$ of hyperglycemic emergency department patients in one study were likewise nondiabetic; ${ }^{50}$ the same finding was true in critically ill medical patients. ${ }^{57}$

There is also a great deal of data that associates such admission hyperglycemia with poor outcomes. This has been shown, albeit retrospectively, with an association between admission hyperglycemia, particularly if persistent, and an increased risk of infectious complications and mortality 


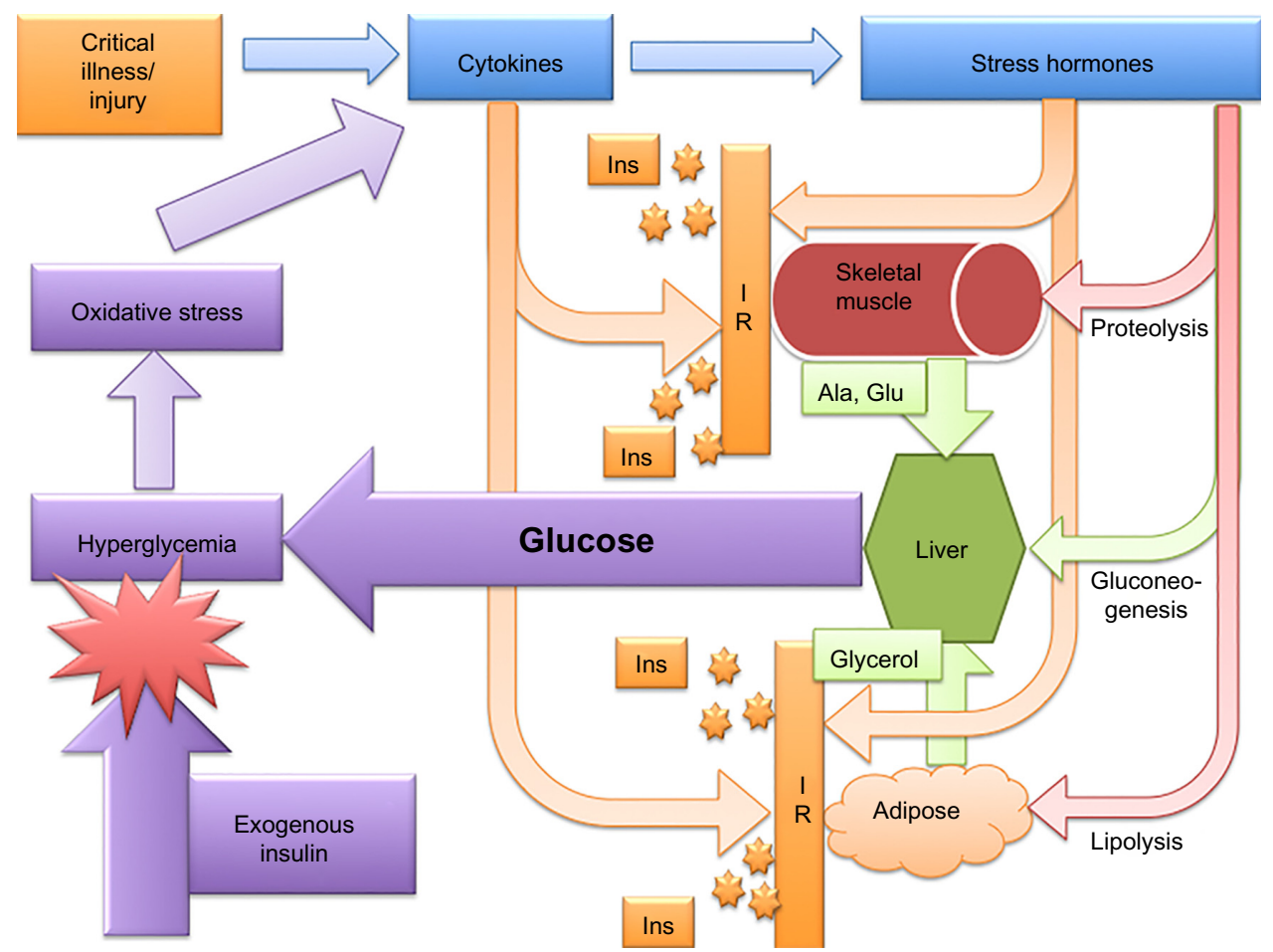

Figure 2 Hyperglycemia and critical illness: a complex interrelationship.

Notes: Critical illness and injury alter mechanisms of glucose mechanisms through release of cytokines (TNF- $\alpha$, IL-I, IL-2, IL-6, IL-8) and in turn the secretion of stress hormones (cortisol, epinephrine, norepinephrine, glucagon, and growth hormone). These separate phenomena result in insulin resistance, as manifested by alterations in the GLUT receptors and decreased adiponectin. These changes result in proteolysis and lipolysis to create substrates that can be utilized for gluconeogenesis by the liver. Elevated glucose production results in serum hyperglycemia, which can further aggravate the cycle of oxidative stress. Reprinted with permission from SURGICAL INFECTIONS, Volume 12, 20I I, pp. 405-4I8, published by Mary Ann Liebert, Inc., New Rochelle, NY, USA. ${ }^{54}$

Abbreviations: Ins, insulin; Ala, alanine; Glu, glutamine; IR, insulin resistance; TNF-a, tumor necrosis factor alpha; IL, interleukin.

even after correction for obesity and diabetes. ${ }^{6,7,58,59}$ Kerby et $\mathrm{al}^{60}$ noted in a study of more than 6,800 trauma patients that mortality was higher in nondiabetic patients with hyperglycemia than in diabetic patients, while both groups were at increased risk for pneumonia. Interestingly, Egi et al ${ }^{61}$ noted that admission hyperglycemia and maximum intensive care unit (ICU) BG levels were actually protective against ICU mortality; this finding is at odds with other work on the subject that found admission hyperglycemia to be associated with mortality ${ }^{58}$ and that acute elevations in serum glucose were associated with ICU mortality after adjusting for age and severity of illness. ${ }^{6}$ Bochicchio et $\mathrm{al}^{7}$ also found that persistent hyperglycemia was predictive of mortality, and Mowery et $\mathrm{al}^{62}$ noted that failure to correct hyperglycemia despite insulin administration was predictive of mortality. The studies from Bochicchio et al, Egi, and Mowery et al are all retrospective, but they involve high numbers of patients, serial BG measurements, and in the case of the Mowery paper, a robust and well-validated insulin protocol. ${ }^{63,64}$ The most notable deficiency of the Egi et al paper ${ }^{61}$ is the absence of a standardized glycemic control protocol across the four ICUs that were studied. Furthermore, only two of the four centers collected information about the diabetic status of patients; Egi et $\mathrm{al}^{65}$ previously demonstrated a significant interaction between the chronic hyperglycemia associated with diabetes and the acute hyperglycemia associated with stress, and concluded that an unspecified degree of permissive hyperglycemia might improve outcomes in critically ill diabetic patients. Thus, the incomplete data collection in this area is a significant shortcoming that might explain the variation in his results.

Once intensivists began treating hyperglycemia, the concept of insulin resistance came to the fore, with some patients requiring a much higher insulin dose than others to maintain their BG in a euglycemic range; thus, there was still a difference between the glucose metabolism among patients even after hyperglycemia had been addressed. Patients who required more insulin to maintain euglycemia (insulin-resistant) were more than twice as likely to have positive blood cultures after injury, ${ }^{66}$ and changes in insulin resistance have been shown to precede the diagnosis of ventilator-associated pneumonia. ${ }^{55}$ The mortality risk is particularly notable for patients with traumatic brain injury; those with elevated insulin resistance, as measured by the amount of insulin required to maintain 
euglycemia, had an odds ratio (OR) for mortality of 1.36 (95\% confidence interval [CI]: $1.01-1.82) .{ }^{67}$ The level of insulin resistance was also associated with mortality in the critically ill postsurgical population, even after controlling for body mass index.$^{68}$ Failure to reach euglycemia despite insulin therapy has also been associated with increased mortality in the trauma population. ${ }^{62}$

Despite a large amount of data in this area, there were no well-conducted randomized trials. Van den Berghe et $\mathrm{al}^{1}$ are credited, appropriately so, with conducting the first randomized controlled trial of what we now consider to be "tight" glycemic control in critically ill patients with a study published in 2001. This study randomized a total of 1,548 mechanically ventilated patients admitted to a single ICU to either intensive control (insulin infusion titrated to maintain serum BG between $80-110 \mathrm{mg} / \mathrm{dL}$ once the serum BG exceeded $110 \mathrm{mg} / \mathrm{dL}$ ) or conventional treatment (insulin infusion titrated to maintain serum BG between 180-200 mg/dL once the serum BG exceeded $215 \mathrm{mg} / \mathrm{dL}$ ). The primary endpoint was all-cause ICU mortality. BG testing was performed at 1-4-hour intervals while patients were on the insulin infusion, and patients received glycemic provision with intravenous glucose during the first 24 hours after admission, followed by enteral or parenteral nutrition starting on the second hospital day. Enteral nutrition was started when felt to be safe by the attending physician. When the patient was discharged from the ICU, the insulin infusion was discontinued, and a sliding scale protocol was initiated to keep BG between 180-200 mg/dL.

Van den Berghe et $\mathrm{al}^{1}$ noted that there was decreased all-cause ICU and hospital mortality in the intensive insulin therapy (IIT) arm (4.6\% versus $8.0 \%$ [risk of ICU mortality]; $P<0.04)$, as well as a reduced incidence of bloodstream infection, reduced number of patients with a duration of mechanical ventilation longer than 5 days, reduced incidence of critical illness polyneuropathy, and a decreased need for hemodialysis. The benefit in mortality was concentrated in patients with multiple organ dysfunction with a septic source. In addition, $5.1 \%$ of patients in the intensive therapy arm (39/765) had at least one serum BG level $<40 \mathrm{mg} / \mathrm{dL}$, whereas severe hypoglycemia only occurred in $0.7 \%(6 / 783)$ of conventional therapy patients. The actual algorithm utilized was not provided, and this rate of severe hypoglycemia is notably higher than what has been reported in other studies using computer-assisted insulin infusion algorithms. ${ }^{69-71}$

This study is notable for several reasons. First, it was novel. Secondly, its study population was relatively unique. A total of $62.6 \%$ of the patients $(970 / 1,548)$ were admitted to the ICU after cardiac surgery. The remainder of the patient population was split among trauma/burn patients; patients with neurological disorders; and patients after vascular, thoracic, or abdominal surgery. Thirdly, this study used a fairly modern and aggressive approach to nutritional supplementation, with the administration of intravenous dextrose during the first 24 hours of admission followed by immediate enteral or parenteral nutrition. This last design parameter is notable in light of recent evidence that early administration of parenteral nutrition may increase ICU mortality, the need for mechanical ventilation, and the rate of ICU infections. ${ }^{74}$ Perhaps the most significant finding was the relationship between hyperglycemia, infection, multiple organ dysfunction, and death. ${ }^{1}$

Although the study from van den Berghe et $\mathrm{al}^{1}$ helped to create a dramatic change in practice in ICUs worldwide, it is worth noting that no other large study since has been able to duplicate the mortality reduction that van den Berghe et al

Table I Key randomized controlled trials evaluating mortality for tight glycemic control in critically ill surgical patients

\begin{tabular}{|c|c|c|c|c|c|}
\hline Author & Patients & Design & $\begin{array}{l}\text { Sample } \\
\text { size }\end{array}$ & Glucose control & $\begin{array}{l}\text { Mortality } \\
\text { OR }(95 \% \mathrm{CI})\end{array}$ \\
\hline Van den & Surgical & $80-110 \mathrm{mg} / \mathrm{dL}$ versus & 765 (GC) & $103 \pm 19(\mathrm{GC})$ & $0.64(0.45-0.91)$ \\
\hline Berghe et al' & & $180-200$ mg/dL & 783 (Cont) & $153 \pm 33$ (Cont) & \\
\hline Grey and & Surgical & $80-120 \mathrm{mg} / \mathrm{dL}$ versus & 34 (GC) & $125 \pm 36(G C)$ & $0.47(0.12-1.86)$ \\
\hline Perdrizet ${ }^{75}$ & & $180-220$ mg/dL & 27 (Cont) & $|79 \pm 6|$ (Cont) & \\
\hline De La & Mixed & $80-110 \mathrm{mg} / \mathrm{dL}$ versus & $252(\mathrm{GC})$ & I20 (IQR: II0-I34) (GC) & $\mathrm{I} .08(0.75-\mathrm{I} .54)$ \\
\hline Rosa et $\mathrm{al}^{76}$ & & $180-200$ mg/dL & 250 (Cont) & I49 (IQR: I24-I80) (Cont) & \\
\hline \multirow[t]{2}{*}{ Arabi et $a l^{77}$} & Mixed & $80-110 \mathrm{mg} / \mathrm{dL}$ versus & 266 (GC) & $115 \pm 18$ (GC) & $0.78(0.53-1.13)$ \\
\hline & & $180-200$ mg/dL & 257 (Cont) & $|7| \pm 34$ (Cont) & \\
\hline Preiser & Mixed & $80-110 \mathrm{mg} / \mathrm{dL}$ versus & $536(\mathrm{GC})$ & II 7 (IQR: I08-I30) (GC) & 1.27 (0.94-I.7) \\
\hline et $\mathrm{al}^{78}$ & & |40-180 mg/dL & 542 (Cont) & I44 (IQR: I28-I62) (Cont) & \\
\hline \multirow[t]{2}{*}{ Finfer et $\mathrm{al}^{79}$} & Mixed & $80-110 \mathrm{mg} / \mathrm{dL}$ versus & 3054 (GC) & $115 \pm 18(G C)$ & $1.09(0.96-1.23)$ \\
\hline & & |40-180 mg/dL & 3050 (Cont) & 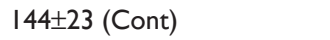 & \\
\hline
\end{tabular}

Abbreviations: OR, odds ratio; $\mathrm{Cl}$, confidence interval; GC, glycemic control arm of study; Cont, control arm of study. IQR, interquartile range. 
Table 2 Investigations on the impact of hyperglycemia and infectious complications

\begin{tabular}{|c|c|c|c|c|c|}
\hline Author & Population & Design & Sample size & Outcome measure & Results \\
\hline Vriesendorp ${ }^{97}$ & $\begin{array}{l}\text { Infrainguinal } \\
\text { vascular surgery }\end{array}$ & Retrospective & 211 & POI & $\begin{array}{l}\text { Postoperative glucose an independent risk } \\
\text { factor for POI }\end{array}$ \\
\hline $\operatorname{Ramos}^{98}$ & $\begin{array}{l}\text { General and } \\
\text { vascular surgery }\end{array}$ & Retrospective & 995 & $\mathrm{POI}$ & $\begin{array}{l}\text { Incremental elevation of postoperative } \\
\text { glucose }(\geq 110 \mathrm{mg} / \mathrm{dL}) \text { a risk factor for } \mathrm{POI} \text { in } \\
\text { multivariable analysis }\end{array}$ \\
\hline $\begin{array}{l}\text { Vilar- } \\
\text { Compte }\end{array}$ & $\begin{array}{l}\text { Mastectomy for } \\
\text { breast cancer }\end{array}$ & $\begin{array}{l}\text { Retrospective } \\
\text { case control }\end{array}$ & 260 & SSI & $\begin{array}{l}\text { One BG level } \geq 150 \mathrm{mg} / \mathrm{dL} \text { an independent risk } \\
\text { factor for } \mathrm{SSI}\end{array}$ \\
\hline Marchant ${ }^{107}$ & $\begin{array}{l}\text { Hip or knee } \\
\text { arthroplasty }\end{array}$ & Retrospective & $1,030,013$ & $\begin{array}{l}\text { POC, including infections } \\
\text { and wound complications }\end{array}$ & $\begin{array}{l}\text { Controlled and uncontrolled diabetes } \\
\text { associated with increased odds of POC }\end{array}$ \\
\hline $\operatorname{Ata}^{112}$ & $\begin{array}{l}\text { General and } \\
\text { vascular surgery }\end{array}$ & Retrospective & $|, 56|$ & SSI & $\begin{array}{l}\mathrm{POG} \geq \mathrm{I} 40 \mathrm{mg} / \mathrm{dL} \text { associated with increased } \\
\text { risk of } \mathrm{SSI} \text { in colorectal surgery; diabetes, but } \\
\text { not POG, associated with increased risk of SSI } \\
\text { in vascular surgery }\end{array}$ \\
\hline Frisch $^{94}$ & $\begin{array}{l}\text { Noncardiac } \\
\text { general surgery }\end{array}$ & $\begin{array}{l}\text { Prospective } \\
\text { observational }\end{array}$ & 3,184 & $\mathrm{POI}$ & Diabetic patients more likely to have $\mathrm{POI}$ \\
\hline King ${ }^{106}$ & $\begin{array}{l}\text { DM, noncardiac } \\
\text { surgery }\end{array}$ & Retrospective & 55,408 & 30-day POI & $\begin{array}{l}\text { Mean } 24 \text {-hour POG } \geq 150 \mathrm{mg} / \mathrm{dL} \text { increased the } \\
\text { risk of POI }\end{array}$ \\
\hline Umpierrez"'I & $\begin{array}{l}\text { Type } 2 \text { DM, } \\
\text { noncardiac } \\
\text { surgery }\end{array}$ & PRMCT & 211 & $\mathrm{POI}$ & $\begin{array}{l}\text { Basal bolus insulin and glulisine with meals } \\
\text { resulted in better glucose control and lower } \\
\text { POI rate }\end{array}$ \\
\hline Jackson ${ }^{135}$ & $\begin{array}{l}\text { Open colectomy } \\
\text { for colon cancer }\end{array}$ & Retrospective & 7,576 & $\mathrm{POI}$ & $\begin{array}{l}\text { Moderate hyperglycemia (BG }|6|-200 \mathrm{mg} / \mathrm{dL} \text { ) } \\
\text { on the day of operation as a risk factor for PO }\end{array}$ \\
\hline Jämsen ${ }^{136}$ & $\begin{array}{l}\text { Primary hip or } \\
\text { knee arthroplasty }\end{array}$ & Retrospective & 7,181 & $\begin{array}{l}\text { Periprosthetic joint } \\
\text { infection }\end{array}$ & $\begin{array}{l}\text { Diabetes and morbid obesity increased the risk } \\
\text { of periprosthetic joint infection }\end{array}$ \\
\hline Richards $^{3}$ & $\begin{array}{l}\text { Orthopedic } \\
\text { trauma without } \\
\text { a history of DM }\end{array}$ & Retrospective & 790 & 30-day SSI & $\begin{array}{l}\text { Postoperative hyperglycemia }(\mathrm{HGI} \geq 1.76 \text { or } \\
\text { two random } B G \geq 200 \mathrm{mg} / \mathrm{dL} \text { ) an independent } \\
\text { risk factor for SSI }\end{array}$ \\
\hline Kwon ${ }^{137}$ & $\begin{array}{l}\text { Elective colon/ } \\
\text { rectal or bariatric } \\
\text { surgery }\end{array}$ & Retrospective & 11,633 & 30-day POI & $\begin{array}{l}\text { Postoperative (POD I or } 2 \text { ) hyperglycemia } \\
\geq 180 \mathrm{mg} / \mathrm{dL} \text { associated with an increased risk } \\
\text { of POI }\end{array}$ \\
\hline Richards $^{5}$ & $\begin{array}{l}\text { Nondiabetic } \\
\text { orthopedic trauma }\end{array}$ & $\begin{array}{l}\text { Prospective } \\
\text { observational }\end{array}$ & 164 & 30-day SSI & $\begin{array}{l}\text { Hyperglycemia (random } B G \geq 200 \mathrm{mg} / \mathrm{dL} \text { or } \\
\text { fasting } B G \geq 125 \mathrm{mg} / \mathrm{dL} \text { ) associated with } \mathrm{SSI}\end{array}$ \\
\hline Wukich ${ }^{109}$ & $\begin{array}{l}\text { Foot and ankle } \\
\text { surgery with DM }\end{array}$ & $\begin{array}{l}\text { Prospective } \\
\text { observational }\end{array}$ & 2,060 & SSI & $\begin{array}{l}\text { Complicated DM and patients with neuropathy } \\
\text { had an increased risk of SSI }\end{array}$ \\
\hline
\end{tabular}

Abbreviations: POI, postoperative infection; SSI, surgical site infection; BG, blood glucose; POC, postoperative complication; POG, postoperative glucose; DM, diabetes mellitus; PRMCT, prospective, randomized, multicenter trial; HGI, hyperglycemic index; POD, postoperative day.

observed (Table 1). ${ }^{75-79}$ Of note, the NICE-SUGAR trial ${ }^{79}$ of 6,104 critically ill patients did not note any mortality benefit in the ICU, but it actually noted an increased OR for mortality in the intensive $(81-108 \mathrm{mg} / \mathrm{dL})$ group as compared to the conventional $(<180 \mathrm{mg} / \mathrm{dL})$ group at 90 days (OR: 1.14 [95\% CI: $1.02-1.28 ; P=0.02]) .{ }^{79}$ Although this patient population contained more trauma patients (14\% as opposed to $4 \%$ in the van den Berghe et al study ${ }^{1}$ ), overall only $36.6 \%$ $(2,233 / 6,104)$ of the patients were postsurgical. The intensive control group had a higher incidence of corticosteroid administration for presumed septic shock, although the incidence of septic shock itself was not different between groups.

Again, the incidence of severe hypoglycemia was dramatically higher in the intensive control $\operatorname{arm}(6.8 \%[206 / 3,016])$ as opposed to the control arm $(0.5 \%[15 / 3,014])$; this was statistically significant with an OR of 14.7 (95\% CI:
9.0-25.9; $P<0.001)$. Some additional credence to the theory that hypoglycemia may play a role is fostered by Griesdale et al's meta-analysis, ${ }^{80}$ which showed a consistent increase in the OR of hypoglycemia in trials with IIT (overall OR of 5.99 [95\% CI: 4.47-8.03]). However, Griesdale et al did not find any significant mortality effect, either positive or negative, from IIT. Other authors, however, have noted a mortality difference. Of note, Krinsley ${ }^{81}$ found that even a single episode of hypoglycemia increased mortality in critically ill patients (OR: 2.28 [95\% CI: 1.41-3.70]; $P=0.0008$ ). Mowery et al ${ }^{71}$ noted the same finding in critically ill postsurgical patients, despite an incidence of severe hypoglycemia of only $4.6 \%$, lower than either the van den Berghe et $\mathrm{al}^{1}$ or the NICE-SUGAR study. ${ }^{79}$ Bagshaw et al ${ }^{82,83}$ found that early hypoglycemia was independently associated with increased mortality. 
Hypoglycemia aside, there are other clear differences between the van den Berghe et al study ${ }^{1}$ and the NICESUGAR study ${ }^{79}$ that may explain the differences in outcome. The NICE-SUGAR trial had a higher proportion of medical patients who even van den Berghe et al found to not share the mortality benefit of tight glycemic control enjoyed by their postsurgical counterparts. ${ }^{84}$ The NICE-SUGAR trial had a higher incidence of hypoglycemia than did the van den Berghe et al study. The NICE-SUGAR investigators were less nutritionally aggressive than their counterparts in the van den Berghe et al study, particularly with parenteral nutrition. This is notable because more aggressive nutritional supplementation with balanced enteral or parenteral nutrition has been shown to be preventive of hypoglycemia when compared to carbohydrate administration alone. ${ }^{69}$ While the deaths in the van den Berghe et al trial were largely associated with sepsis, most of the deaths in the NICE-SUGAR trial were from a cardiovascular origin. Also unlike van den Berghe et al's study, the NICE-SUGAR investigation does not reveal any significant differences in ICU morbidity.

Griesdale et al's meta-analysis, ${ }^{80}$ mentioned earlier, does suggest that surgical patients may have a mortality benefit from IIT, but a closer examination of this group reveals that it is dominated by van den Berghe et al's study; ${ }^{1}$ thus, it is difficult to determine if this is a true effect. On the other hand, none of the studies referenced earlier have found a significant effect of diabetes predating the critical illness in the outcome of patients, lending credibility to the theory that chronic hyperglycemia due to DM, and acute hyperglycemia due to stress and critical illness, may have relatively independent effects on mortality in this patient population. ${ }^{1,79}$

Therefore, the mortality effects, in either direction, of IIT remain unclear. It is unlikely that another large trial will be initiated to answer the question given that a multicenter randomized controlled trial (NICE-SUGAR) with more than 6,000 patients did not yield a statistically significant result. ${ }^{79}$ It is likely, however, that the risks of hypoglycemia have been underappreciated in the quest to achieve tight glycemic control, and that hypoglycemia likely has significant effects on mortality. In light of recent studies, the practice at our institution has changed; although we still pursue relatively robust glycemic control, we predominantly aim for a serum BG level $<150 \mathrm{mg} / \mathrm{dL}$. In the absence of data from prospective randomized clinical trials in surgical patients, this practice pattern is based on the most recent guidelines proposed by Jacobi et al..$^{85}$

The focus on mortality alone in this section is deliberate. Although the mortality benefits of glycemic control have not been clearly demonstrated through the preponderance of available studies, there is a well-developed relationship between hyperglycemia and infectious morbidity that merits consideration, particularly in critically ill patients recovering from a surgical insult.

\section{Glycemic variability}

The effects of hyperglycemia and insulin resistance are intimately intertwined with the concept of glycemic variability, the amount of variation in the BG level of a patient that is noted with repeated measurements. This glycemic variability is derived from two separate components, the first being changes in native insulin resistance that may be associated with infection, ${ }^{55}$ and the second is the effect of exogenous insulin therapy itself. Although investigators vary widely in their measurement of BG variability, Braithwaite ${ }^{86}$ and Braithwaite et $\mathrm{al}^{87}$ lent some statistical rigor to the term via a logarithmic transformation of raw $\mathrm{BG}$ data that then underwent a reverse transformation to establish group means for different populations; this method has since undergone clinical validation.

While insulin therapy can adequately treat hyperglycemia, the effect of BG variability is to increase mortality, regardless of the $\mathrm{BG}$ level. ${ }^{88}$ Bagshaw et a ${ }^{82,83}$ likewise found that $B G$ variability was independently associated with increased mortality. Egi et al's ${ }^{61}$ retrospective study of more than 7,000 patients found that both the mean BG level and its standard deviation were associated with increased mortality; the OR for the 30-day mortality following an increase of $1 \mathrm{mmol}$ in the standard deviation of serum BG levels was 1.28 (95\% CI: 1.14-1.44]. A study of more than 30 Dutch ICUs found some differences in which measurements of glycemic variability were related to mortality in surgical as opposed to medical patients; the standard deviation of serum BG was associated with increased mortality in all patient populations. ${ }^{89}$

Kauffmann et $\mathrm{al}^{70}$ further noted that BG variability was a harbinger of hypoglycemia, and their study was conducted in an institution with a lower rate of hypoglycemia than the results from the NICE-SUGAR study. ${ }^{71}$ Although the incidence of $\mathrm{BG}<40 \mathrm{mg} / \mathrm{dL}$ was not reported, the incidence of $\mathrm{BG}<50 \mathrm{mg} / \mathrm{dL}$ was $11.1 \%{ }^{70}$ This study is significant because it is not necessarily intuitive as to why increased glycemic variability should be associated with mortality; Kauffmann et al's work suggests that the relationship between BG variability and hypoglycemia might provide a mechanism for increased mortality in the critically ill. Of note, Krinsley ${ }^{90}$ found that increased $\mathrm{BG}$ variability, as measured by the standard deviation of serum BG divided by the mean 
serum BG (coefficient of variability), was associated with increased mortality in nondiabetic patients, whether they had a serum BG target range of $80-140 \mathrm{mg} / \mathrm{dL}$ or no target range, and that the relationship persisted even after adjusting for hypoglycemia. Egi and Bellomo ${ }^{91}$ postulate that glycemic variability might be inherently deleterious due to increased levels of oxidative stress via the protein kinase $\mathrm{C}$ pathway; they also suggest that glycemic variability might be a surrogate for poor care or more severe illness.

On the other hand, there was no relationship between BG variability and mortality in critically ill diabetic patients, corroborating Egi's theory ${ }^{65}$ that preexisting diabetes might be protective against some of the deleterious effects of acute hyperglycemia. Sechterberger et $\mathrm{al}^{92}$ also found that mean $\mathrm{BG}$ and $\mathrm{BG}$ variability (as measured by the mean absolute change in serum BG level) were also only related to mortality in diabetics.

As previously mentioned, in the setting of a highly effective and accurate glycemic control protocol, a great deal of the glycemic variability that would otherwise be apparent may be dampened. Even if the BG level stays the same due to aggressive and effective BG control, the amount of sensitivity to insulin may change dramatically in ICU patients with time. Pretty et $\mathrm{al}^{93}$ noted that patients are much less insulin-resistant on their first ICU day as compared to subsequent days, and thus may be more vulnerable to hypoglycemia early in their ICU stay. We have also demonstrated that, even after accounting for infection, there is an increase in the level of insulin resistance as patients move farther into their ICU course. ${ }^{55}$ Unpublished work from our group indicates that this finding is still noted even after adjusting for the amount of glycemic provision (Mukherjee et al, unpublished data, 2015). It is possible, therefore, that glycemic variability is merely the external manifestation of changes in insulin resistance that are incompletely understood, potentially increased in surgical patients, and not present or decreased in significance in patients with chronic hyperglycemia and insulin resistance due to DM.

\section{Hyperglycemia and infection in surgical patients}

Hyperglycemia is a well-established risk factor for infectious complications in surgical patients. Much of the initial data gathered on elevated BG and postoperative infectious morbidity were related to patients with a history of DM. Patients with DM were more likely to suffer from postoperative infectious complications, including pneumonia, urinary tract infections, sepsis, and SSI. ${ }^{94}$ A considerable amount of clinical investigations in cardiac surgery patients revealed that elevated
BG in excess of $200 \mathrm{mg} / \mathrm{dL}$ was associated with a significant increase in postoperative infectious risk. ${ }^{95,96}$ Furthermore, subsequent studies have identified that the increased infection risk is not isolated to patients with a history of DM, and that hyperglycemia in nondiabetic patients may portend a worse clinical outcome (Table 2). ${ }^{97-100}$ Given the increased attention to nosocomial infections and "never" events, hyperglycemia has remained the focus of potential modifiable risk factors in the prevention of postoperative complications.

Hyperglycemia in the setting of poorly controlled DM results in the production of advanced glycosylation end products, which accumulate in and affect extracellular matrix production. This pathophysiologic response is manifested by alterations in cellular function, including impaired leukocyte function and chemotaxis, decreased phagocytosis, ineffective bacterial eradication, and overall decreased immune responsiveness. ${ }^{101}$ In addition, hyperglycemia in DM is known to result in impaired collagen synthesis, which is associated with delayed wound healing. ${ }^{102,103}$ This decreased collagen framework, along with the microvascular changes directed by reactive oxygen species production via hyperglycemia, is responsible for poor tissue perfusion. ${ }^{104}$ In addition to these alterations in cellular function, hyperglycemia also promotes a state of hyperinflammation. Increased cytokines, such as TNF- $\alpha$, IL- 6 , and plasminogen activator inhibitor, results in increased vascular permeability, platelet activation, and endothelial dysfunction. ${ }^{104}$ In summary, the altered physiologic environment observed with hyperglycemia creates a cellular milieu that promotes invasion by infectious sources. ${ }^{58}$

The clinical impact of hyperglycemia and postoperative infections was initially established in cardiac surgery patients. Latham et $\mathrm{al}^{95}$ reported that a history of DM and postoperative hyperglycemia ( $\mathrm{BG} \geq 200 \mathrm{mg} / \mathrm{dL}$ ) were significant risk factors for SSI. This increased risk remained true even for hyperglycemic patients without a history of DM. The association with hyperglycemia and postoperative infectious complications was further corroborated by Funary et al, ${ }^{105}$ who described a continuous insulin infusion protocol by which a targeted BG of $<150 \mathrm{mg} / \mathrm{dL}$ was associated with a significantly decreased risk for deep sternal wound infections. Furthermore, hyperglycemia and poor intraoperative glycemic control were associated with poor hospital outcomes, including increased infectious complications, in diabetic cardiac surgery patients. ${ }^{96}$ These findings have also been extended to other diabetic patient populations, including general surgery, gynecologic surgery, surgical oncology, and orthopedic surgery. ${ }^{94}$ King et al ${ }^{106}$ described, in a large 
study from the Veterans Health Administration nationwide database, that mean serum glucose concentrations $\geq 150$ $\mathrm{mg} / \mathrm{dL}$ during the first postoperative day were associated with increased postoperative infections in diabetic patients undergoing noncardiac surgery. In addition, Frisch et al, ${ }^{94}$ in a similar population of noncardiac surgery patients, noted that infectious complications were more common in patients with diabetes. Other surgical subspecialties have also confirmed that diabetic status imparts a significant risk for postoperative infection. Multiple studies in orthopedic surgery have identified that diabetes is associated with a significantly increased risk for postoperative wound infections in patients with DM. Marchant et $\mathrm{al}^{107}$ and Olsen et al ${ }^{108}$ identified that patients with diabetes were at a greater of risk of postoperative wound complications following joint arthroplasty and spinal operations, respectively. Similarly, Wukich et al ${ }^{109}$ recently described, from a prospective cohort of patients following foot and ankle surgery, that uncontrolled DM and peripheral neuropathy were associated with infectious wound complications.

Even though the association of hyperglycemia and infectious complications in diabetic patients has been well described throughout the surgical literature, perhaps of even greater interest is the impact of hyperglycemia and postoperative morbidity in patients without a history of DM. As previously discussed, Latham et $\mathrm{a}^{95}$ noted that hyperglycemia was a risk factor for deep sternal wound infections in both diabetic and nondiabetic cardiac surgery patients. The stress response following surgical and anesthetic-related stimuli are known to increase the production of catecholamines, growth hormones, and cortisol, in addition to upregulating inflammatory cytokines. ${ }^{110,111}$ These mechanisms result in alterations in glucose metabolism, such as increased gluconeogenesis, glycogenolysis, and insulin resistance, all of which contribute to a state of hyperglycemia. Further investigation by Ramos et $\mathrm{al}^{98}$ noted that postoperative glucose was a risk factor for infectious complications in patients undergoing general and vascular surgery. This risk increased incrementally for BG values $\geq 110 \mathrm{mg} / \mathrm{dL}$ and was independent of a history of DM. Similarly, Ata et $\mathrm{al}^{112}$ reported that the likelihood of postoperative SSI increased progressively for patients with elevated BG values. Multivariable logistic regression modeling, adjusting for potential confounding variables, identified that elevated postoperative glucose values remained the single most important predictor of SSI, and this remained independent of a previous history of diabetes. Park et $\mathrm{al}^{99}$ also identified that while a history of DM was not associated with postoperative SSI, severe intraoperative hyperglycemia
(BG $\geq 200 \mathrm{mg} / \mathrm{dL}$ ) was a significant independent risk factor in patients who underwent liver transplantation. Two investigations in orthopedic trauma patients documented an increased risk of 30-day SSI in hyperglycemic patients who were without a history of DM., ${ }^{3,4}$ The risk of infection in patients with hyperglycemia was even greater than the risk of infection from an open fracture. ${ }^{3}$ Furthermore, trends in BG and acute glucose elevation may be useful tools in predicting infection in critically injured trauma patients. ${ }^{6}$ Most recently, Kiran et $\mathrm{al}^{100}$ demonstrated that a single elevated BG value within 72 hours after surgery was associated with postoperative infectious complications in colorectal surgery patients. Considering these findings, it is widely believed that the impact of hyperglycemia on infectious complications is exceedingly greater in nondiabetic surgical patients. While the precise etiology is not elucidated, the pathophysiologic mechanisms of acute glucose elevation following surgical stress may be magnified in patients who are otherwise unaccustomed to the effects of hyperglycemia.

Despite the widespread interest and clinical data supporting the detrimental effects of hyperglycemia in surgical patients, there exists significant discussion regarding the optimal management of elevated BG in these patients. The landmark study by van den Berghe et $\mathrm{al}^{1}$ established the role of tight glycemic control in a population of critically ill surgical patients and demonstrated a reduction in infectious complications; however, these results have been difficult to corroborate in similar patient populations. ${ }^{79}$ While the precise level of glucose control remains the subject of considerable debate, there is sufficient data to support that persistent hyperglycemia negatively affects clinical outcomes. Perhaps one of the most frequently investigated populations is that of critically injured trauma patients, where admission hyperglycemia, ${ }^{58,113-115}$ acute fluctuations in glucose levels, ${ }^{6}$ and persistent hyperglycemia ${ }^{7}$ have been correlated with adverse outcomes. Recent studies have suggested that insulin therapy is associated with a reduction in infectious complications in this critically injured trauma population. ${ }^{59}$ In addition, a prospective, randomized study in diabetic noncardiac surgery patients revealed that basal bolus insulin therapy was superior to sliding scale insulin and reduced infectious complications and mortality. ${ }^{111}$ To date, however, there are no randomized studies evaluating hyperglycemia management and the level of BG control in nondiabetic surgical patients. While the impact of hyperglycemia on infectious complications has generated considerable attention throughout the last two decades, further multicenter, randomized studies are necessary in order to validate previous investigations and 
establish a potential role for optimal glycemic management as a method to reduce postoperative infectious complications in surgical patients. The risks of hyperglycemia must also be balanced against the counterweight of hypoglycemiainduced neurologic morbidity that is especially important in the critically ill.

\section{Risks of hypoglycemia}

Hypoglycemia is a known risk factor for mortality in hospitalized patients. ${ }^{116,117}$ The documented incidence of severe hypoglycemia ( $\mathrm{BG}<40 \mathrm{mg} / \mathrm{dL}$ ) associated with IIT varies from $0.34 \%-18.7 \%$ depending on the patient population and targeted BG values. ${ }^{1,79,84,118-121}$ In the van den Berghe et al study, ${ }^{1} 39$ out of 765 patients in the intensive-treatment group experienced severe hypoglycemia compared to only six out of 783 patients in the conventional treatment group. The NICE-SUGAR trial ${ }^{79}$ demonstrated an increased risk of death (conventional control, $24.9 \%$ versus intensive control, $27.5 \% ; P=0.02$ ) along with an increased incidence of severe hypoglycemia with IIT. Two hundred and six patients of 3016 $(6.8 \%)$ in the intensive control group experienced severe hypoglycemia while only $15(0.5 \%)$ in the conventional control group were severely hypoglycemic $(P<0.001) .{ }^{79}$ Studies examining critically ill trauma and/or surgical patients have shown the incidence of severe hypoglycemia to be as low as $0.6 \%$ with no increase in mortality. ${ }^{71,122}$ The variability in the incidence of hypoglycemia and mortality reported in the literature indicates that factors other than IIT play a role in the risk of hypoglycemia.

Several studies have indicated that BG variability is a significant risk factor for mortality and the development of hypoglycemia in the critically ill population..$^{70,82,123-125}$ When looking at surgical ICU patients, Kauffman et $\mathrm{al}^{70}$ found a patient's BG variability increased in the 24 hours that preceded his or her hypoglycemic event. In another study examining critically ill surgical patients receiving IIT, ICU survivors and nonsurvivors had similar mean BG values over time, but the nonsurvivors had significantly more BG variability $(P<0.001)$. Increased BG variability was associated with an increased risk of death. ${ }^{123}$ This finding was confirmed in a 2012 study where the risk of mortality increased with increased BG variability (adjusted relative risk: 1.61 ; 95\% CI: 1.47-1.78). ${ }^{125}$ This demonstrates the importance of minimizing BG variability while on IIT.

One factor that may prevent hypoglycemia during IIT is a consistent nutrition source. A study comparing enteral and parenteral nutrition to carbohydrate-only nutrition in patients receiving IIT found that a balanced nutrition source with enteral or parenteral nutrition was the strongest protective factor against the occurrence of hypoglycemia. ${ }^{69}$ Another study looking at risk factors for severe hypoglycemia showed that $56.8 \%$ of patients who developed severe hypoglycemia were not receiving any nutritional therapy. However, the lack of nutrition source was not shown to be a significant risk factor for severe hypoglycemia in a multivariate logistic regression analysis. ${ }^{118}$

Critically ill surgical patients often require lifesustaining measures, such as mechanical ventilation and renal replacement therapy, during their ICU admission. Both of these interventions have been associated with severe hypoglycemia. In a mixed medical and surgical ICU population, the use of bicarbonate-based substitution fluid during continuous venovenous hemofiltration was found to be associated with severe hypoglycemia (OR: 14; 95\% CI: 1.8-106). ${ }^{119}$ A study by Krinsley and Grover ${ }^{118}$ demonstrated that the presence of renal insufficiency (OR: 1.10; 95\% CI: 0.68-1.77) and mechanical ventilation (OR: 2.11; 95\% CI: 1.28-3.48) were both independent predictors for the development of severe hypoglycemia along with IIT (OR: 1.59; 95\% CI: 1.05-2.41). They also revealed that even a single episode of severe hypoglycemia was independently associated with an increased risk of mortality.

Comorbidities and predisposing patient characteristics have also been indicated as risk factors for hypoglycemic events. A previous diagnosis of diabetes (OR: 4.41; 95\% CI: 2.28-8.50) and female sex (OR: 2.04; 95\% CI: 1.02-4.07) were shown to be risk factors for severe hypoglycemia in medical-surgical ICU patients. ${ }^{120}$ Vriesendorp et al ${ }^{119}$ examined medical-surgical patients and also found diabetes to be a risk factor for hypoglycemia (OR: 2.6; 95\% CI: 1.5-4.7). Patients who develop septic shock, require vasopressor support, or have a high severity of illness while on IIT have demonstrated an increased risk of severe hypoglycemia. ${ }^{18,119}$

In contrast to the previously mentioned studies, a study by Mowery et $\mathrm{al}^{71}$ examining only surgical ICU patients found that patient demographic factors were not associated with severe hypoglycemia. Instead, the duration of time on the intensive insulin protocol was associated with severe hypoglycemia (OR: 1.02; 95\% CI: 1.07-1.15). ${ }^{71}$ This highlights the differences seen in the medical and surgical populations and the need to examine these populations separately in studies.

An additional factor to consider separately involves the critical care management of severe derangements in physiology associated with poorly controlled type 1 and 2 diabetes. These derangements, in the form of diabetic 
ketoacidosis and hyperglycemic hyperosmolar state, are not only associated with significant mortality, but they are also associated with significant complications, including hypoglycemia, in the face of incorrect management. ${ }^{74,75}$

\section{Using computer-assisted glycemic control protocols to minimize hyperglycemia and hypoglycemia}

Titrating insulin is a complicated process. In particular, there are numerous variables that need to be kept in mind. These include the previous BG measurement, the insulin infusion rate, the insulin sensitivity of the patient, the amount of nutrition provided, and any previous episodes of hypoglycemia. The BG and insulin infusion rate need to be monitored on an hourly basis in many cases. In addition, the risks of inducing a hypoglycemic event can be grave. The combination of the actual calculations required, in combination with charting required to document changes in $\mathrm{BG}$ level and insulin rate, significantly increase nursing workload. As a result, the process of blood glucose management in the critically ill patient lends itself to computer analysis.

Numerous studies have been performed on alternative methods of computer-assisted BG control systems. The Glucommander system, developed by Davidson et al, ${ }^{126}$ is based on a linear regression model developed by White et al ${ }^{128}$ in 1982 using a multiplier (a correlate for the patient's insulin sensitivity) multiplied by the serum BG minus $60 \mathrm{mg} / \mathrm{dL}$ to determine the insulin dose for the next hour. Its safety was demonstrated over more than 120,000 hours with a rate of hypoglycemia, as defined as $\mathrm{BG}<50$, that was $0.6 \%$ and a rapid equilibration of serum $\mathrm{BG}$ levels (mean $\mathrm{BG},<150$ $\mathrm{mg} / \mathrm{dL}, 3$ hours after initiation of the protocol). The Glucommander system was also studied in a multicenter randomized trial, showing a more rapid institution of euglycemia (4.8 \pm 2.8 hours versus $7.8 \pm 9.1$ hours; $P<0.01)$ and a higher percentage of BG values in the target range of $80-120 \mathrm{mg}$ / $\mathrm{dL}(71.0 \% \pm 17.0 \%$ versus $51.3 \pm 19.7 \% ; P<0.001)$. However, in this case, there was no change in the incidence of severe hypoglycemia (3.9\% versus $5.6 \%$ [3.9\% is the rate of severe hypoglycemia in the Glucommander group and 5.6\% is the rate of severe hypoglycemia in the standard group]). ${ }^{128}$

The Vanderbilt group ${ }^{63}$ wrote one of the first studies in this area to focus more heavily on the efficacy of computerassisted control systems, comparing a computer-assisted protocol to the previously used manual titration protocol in critically ill trauma patients on an insulin infusion. The BG target in this study was the $80-110 \mathrm{mg} / \mathrm{dL}$ range specified by van den Berghe et al in 2001. ${ }^{1}$ The protocol uses a methodology very similar to the Glucommander. The computer-assisted arm demonstrated superiority in three key areas. Specifically, the computerized arm had $41.8 \%$ of BG values in the range of $80-110 \mathrm{mg} / \mathrm{dL}$, as opposed to $34.0 \%$ in the manual titration protocol $(P<0.001)$. Even with the less stringent controls recommended by the Society of Critical Care medicine ( $\mathrm{BG} \leq 150 \mathrm{mg} / \mathrm{dL}$ ), the computerized protocol was superior, with only $12.8 \%$ of BG measurements $>150 \mathrm{mg} / \mathrm{dL}$ as opposed to $15.1 \%$ in the manual titration arm. Finally, the computerized arm had a significantly lower incidence of severe hypoglycemia $(\mathrm{BG}<40 \mathrm{mg} / \mathrm{dL} ; 0.2 \%$ versus $0.5 \% ; P<0.001) .{ }^{63}$ An additional side benefit of the computerized system was more rapid control, with patients who were hyperglycemic at the initiation of the protocol coming in range within approximately 5 hours. The same system was also validated in critically ill postsurgical patients. ${ }^{64}$ The STAR-Liege system uses a similar approach, it but predicts and continuously adjusts for a range of possibilities of insulin infusion rates and $\mathrm{BG}$ rates rather than a single value; it has also been studied and found to be more effective than a nurse-controlled protocol. ${ }^{129}$

The EndoTool ${ }^{\mathrm{TM}}$, designed by Hospira, Inc. (Lake Forest, IL, USA), also uses a mathematical model to generate a BGmanagement protocol that is individualized to a particular patient. This system is advantageous in that it also calculates the safe BG monitoring interval (the Glucommander and Vanderbilt systems both depend on BG checks every 1-2 hours) and automatically interfaces with the electronic medical record via a dedicated Citrix server, thus decreasing nursing workload. ${ }^{130}$ Like the other studies, the study uses a historical control and demonstrates a dramatic decrease in the rate of severe hypoglycemia $(\mathrm{BG}<40)$ from $1 \%$ to a range from $0 \%-0.12 \%$, depending on the ICU involved, which was both statistically and clinically significant $(P<0.0001)$. Fogel et $\mathrm{al}^{130}$ also found a temporally associated decrease in health care-acquired infections (ventilator-associated pneumonia, catheter-associated urinary tract infections, and central line-associated blood stream infections).

The LOGIC-I software program, designed at the Leuven Hospital in the Netherlands that also conducted the van den Berghe study in 2001, incorporates an additional number of patient variables into its model (reason for ICU admission, the presence of diabetes, body mass index, severity of illness, and nutrition) that are included less completely in other models. ${ }^{132}$ Like the EndoTool, the LOGIC-I software is able to extend the BG testing interval in patients with more stable BG and does not rely on hourly measurements. When compared to a nurse-controlled protocol, the LOGIC-I 
software delivered more time in the target range of 80-110 $\mathrm{mg} / \mathrm{dL}(68.6 \% \pm 16.7 \%$ versus $60.1 \% \pm 18.8 \%)$. Although the number of severe hypoglycemia events was reduced in the LOGIC-I arm $(0 \%$ versus $0.13 \% ; P=0.015)$, the rate of hypoglycemia per patient was not statistically different $(0 \%$ versus $3.3 \% ; P=0.06){ }^{132}$

With the documented effectiveness of these computerized systems in the literature, it is worth considering why they are not employed universally. Campion et al ${ }^{132}$ noted that the primary barriers to implementation included concerns about nursing workload, difficulties with the user interface, inadequate built-in reminders in the interface, and concern for errors. The last concern, particularly as it relates to hypoglycemia, is paramount, and is probably the most likely reason why nurses override the recommendations of a computer-assisted BG protocol. Of 9,075 nurse overrides among 179,452 recommended doses, $83.4 \%$ of overrides reduced the insulin dose suggested by the protocol, and in $45.5 \%$ the override dose was less than half of the recommended dose. ${ }^{133}$ Although these overrides may have prevented hypoglycemic events, they tended to keep patients above the recommended BG range.

Increased computerization of ICUs may result in increased utilization of computer-assisted BG control systems. As they are more frequently used, there is no doubt that nursing staff will gain more familiarity with their use and override their recommendation less often. Furthermore, they will likely become more integrated with the medical record, more transparent, and more efficient, contributing less to nursing workload and likely proving more beneficial for patient care.

\section{Summary}

The era of true "tight" glycemic control in surgical patients, with the aggressive maintenance of a serum BG level between $80-110 \mathrm{mg} / \mathrm{dL}$, is likely over. Recent recommendations from Jacobi et al suggest a less aggressive course with serum BG $<150 \mathrm{mg} / \mathrm{dL} .{ }^{85}$ Avoidance of hypoglycemia through a combination of protocol modification and early and aggressive enteral nutrition has become a preferred goal due to the increased mortality and numerous harms associated with hypoglycemia.

On the other hand, although the mortality benefits that were once associated with strict glycemic control have not been duplicated in large randomized clinical trials since the original van den Berghe publication, ${ }^{1}$ there is a significant and growing body of evidence that uncontrolled hyperglycemia poses an unacceptable risk of infection in the postsurgical population. Therefore, although the $80-110 \mathrm{mg} / \mathrm{dL}$ goal may be too aggressive, allowing consistent serum BG levels above $150 \mathrm{mg} / \mathrm{dL}$ is likely also detrimental. The role of presurgical DM is yet to be conclusively determined. Although poorly controlled DM is clearly a risk factor for poor outcomes after surgery, it may not be clearly related with acute hyperglycemia due to stress and critical illness.

Numerous advances in the field have centered on management of the enormous amounts of data generated by hourly BG management, with multiple protocols available to provide computerized assistance to the bedside provider. These protocols, however, do not always provide sufficient or completely correct guidance in the setting of specialized cases such as diabetic ketoacidosis and hyperglycemic hyperosmolar state; in particular, these conditions cannot be corrected too rapidly due to fear of neurologic complications. These cases aside, there is clearly a role for computer assistance and protocolbased management to ensure appropriate management of hyperglycemia while simultaneously minimizing the risk of hypoglycemia in the critically ill postsurgical patient.

\section{Disclosure}

KM has received funding from the Surgical Infection Society Resident Research Fellowship Award. The authors report no conflicts of interest in this work.

\section{References}

1. van den Berghe $\mathrm{G}$, Wouters $\mathrm{P}$, Weekers $\mathrm{F}$, et al. Intensive insulin therapy in critically ill patients. $N$ Engl J Med. 2001;345(19): 1359-1367.

2. Siddle K. Signalling by insulin and IGF receptors: supporting acts and new players. J Mol Endocrinol. 2011;47(1):R1-R10.

3. Richards JE, Kauffmann RM, Zuckerman SL, Obremskey WT, May AK. Relationship of hyperglycemia and surgical-site infection in orthopaedic surgery. J Bone Joint Surg Am. 2012;94(13):1181-1186.

4. Richards JE, Hutchinson J, Mukherjee K, et al. Stress hyperglycemia and surgical site infection in stable nondiabetic adults with orthopedic injuries. J Trauma Acute Care Surg. 2014;76(4):1070-1075.

5. Richards JE, Kauffmann RM, Obremskey WT, May AK. Stress-induced hyperglycemia as a risk factor for surgical-site infection in nondiabetic orthopedic trauma patients admitted to the intensive care unit. J Orthop Trauma. 2013;27(1):16-21.

6. Bochicchio GV, Bochicchio KM, Joshi M, Ilahi O, Scalea TM. Acute glucose elevation is highly predictive of infection and outcome in critically injured trauma patients. Ann Surg. 2010;252(4): 597-602.

7. Bochicchio GV, Sung J, Joshi M, et al. Persistent hyperglycemia is predictive of outcome in critically ill trauma patients. J Trauma. 2005;58(5):921-924.

8. Garg R, Hurwitz S, Turchin A, Trivedi A. Hypoglycemia, With or Without Insulin Therapy, Is Associated With Increased Mortality Among Hospitalized Patients. Diabetes Care. 2013;36(5):1107-10.

9. Kagansky N, Levy S, Rimon E, et al. Hypoglycemia as a predictor of mortality in hospitalized elderly patients. Archives of Internal Medicine. 2003;163(15):1825-1829.

10. Krinsley JS, Grover A. Severe hypoglycemia in critically ill patients: Risk factors and outcomes*. Critical Care Medicine. 2007;35(10):2262-2267. 
11. Copps KD, White MF. Regulation of insulin sensitivity by serine/ threonine phosphorylation of insulin receptor substrate proteins IRS1 and IRS2. Diabetologia. 2012;55(10):2565-2582.

12. Belfiore A, Frasca F, Pandini G, Sciacca L, Vigneri R. Insulin receptor isoforms and insulin receptor/insulin-like growth factor receptor hybrids in physiology and disease. Endocr Rev. 2009;30(6):586-623.

13. Heydrick SJ, Jullien D, Gautier N, et al. Defect in skeletal muscle phosphatidylinositol-3-kinase in obese insulin-resistant mice. J Clin Invest. 1993;91(4):1358-1366.

14. Pedersen BK. IL-6 signalling in exercise and disease. Biochem Soc Trans. 2007;35(Pt 5):1295-1297.

15. Okamoto M, White MF, Maron R, Kahn CR. Autophosphorylation and kinase activity of insulin receptor in diabetic rats. Am J Physiol. 1986;251(5 Pt 1):E542-E550.

16. Arkan MC, Hevener AL, Greten FR, et al. IKK-beta links inflammation to obesity-induced insulin resistance. Nat Med. 2005;11(2): 191-198.

17. Myers MG, Grammer TC, Brooks J, et al. The pleckstrin homology domain in insulin receptor substrate-1 sensitizes insulin signaling. J Biol Chem. 1995;270(20):11715-11718.

18. Cai D, Yuan M, Frantz DF, et al. Local and systemic insulin resistance resulting from hepatic activation of IKK-beta and NF-kappaB. Nat Med. 2005;11(2):183-190.

19. Rui L, Yuan M, Frantz D, Shoelson S, White MF. SOCS-1 and SOCS-3 block insulin signaling by ubiquitin-mediated degradation of IRS1 and IRS2. J Biol Chem. 2002;277(44):42394-42398.

20. Myers MG Jr, Sun XJ, White MF. The IRS-1 signaling system. Trends Biochem Sci. 1994;19(7):289-293.

21. Patti ME, Sun XJ, Bruening JC, et al. 4PS/insulin receptor substrate (IRS)-2 is the alternative substrate of the insulin receptor in IRS-1deficient mice. J Biol Chem. 1995;270(42):24670-24673.

22. Jamieson E, Chong MM, Steinberg GR, et al. Socs1 deficiency enhances hepatic insulin signaling. J Biol Chem. 2005;280(36) 31516-31521.

23. Guo S, Copps KD, Dong X, et al. The Irs1 branch of the insulin signaling cascade plays a dominant role in hepatic nutrient homeostasis. Mol Cell Biol. 2009;29(18):5070-5083.

24. Klover PJ, Clementi AH, Mooney RA. Interleukin-6 depletion selectively improves hepatic insulin action in obesity. Endocrinology. 2005;146(8):3417-3427.

25. Uchida T, Myers MG, White MF. IRS-4 mediates protein kinase B signaling during insulin stimulation without promoting antiapoptosis. Mol Cell Biol. 2000;20(1):126-138.

26. Dandona P, Aljada A, Bandyopadhyay A. Inflammation: the link between insulin resistance, obesity and diabetes. Trends Immunol. 2004;25(1):4-7.

27. Villar M, Serrano R, Gallardo N, Carrascosa JM, Martinez C, Andrés A. Altered subcellular distribution of IRS-1 and IRS-3 is associated with defective Akt activation and GLUT4 translocation in insulinresistant old rat adipocytes. Biochim Biophys Acta. 2006;1763(2): 197-206.

28. Wellen KE, Hotamisligil GS. Inflammation, stress, and diabetes. J Clin Invest. 2005;115(5):1111-1119.

29. Escribano O, Arribas M, Valverde AM, Benito M. IRS-3 mediates insulin-induced glucose uptake in differentiated IRS-2(-/-) brown adipocytes. Mol Cell Endocrinol. 2007;268(1-2):1-9.

30. Lingohr MK, Dickson LM, Wrede CE, McCuaig JF, Myers MG Jr, Rhodes CJ. IRS-3 inhibits IRS-2-mediated signaling in pancreatic beta-cells. Mol Cell Endocrinol. 2003;204(1-2):85-99.

31. Sadagurski M, Dong XC, Myers MG, White MF. Irs 2 and Irs4 synergize in non-LepRb neurons to control energy balance and glucose homeostasis. Mol Metab. 2014;3(1):55-63.

32. Tsuruzoe K, Emkey R, Kriauciunas KM, Ueki K, Kahn CR. Insulin receptor substrate 3 (IRS-3) and IRS-4 impair IRS-1- and IRS-2mediated signaling. Mol Cell Biol. 2001;21(1):26-38.

33. Saltiel AR, Kahn CR. Insulin signalling and the regulation of glucose and lipid metabolism. Nature. 2001;414(6865):799-806.
34. Copps KD, Hancer NJ, Opare-Ado L, Qiu W, Walsh C, White MF. Irs1 serine 307 promotes insulin sensitivity in mice. Cell Metab. 2010;11(1): 84-92.

35. Carlson CJ, White MF, Rondinone CM. Mammalian target of rapamycin regulates IRS-1 serine 307 phosphorylation. Biochem Biophys Res Commun. 2004;316(2):533-539.

36. Biddinger SB, Kahn CR. From mice to men: insights into the insulin resistance syndromes. Annu Rev Physiol. 2006;68:123-158.

37. Um SH, D'Alessio D, Thomas G. Nutrient overload, insulin resistance, and ribosomal protein S6 kinase 1, S6K1. Cell Metab. 2006;3(6): 393-402.

38. Leto D, Saltiel AR. Regulation of glucose transport by insulin: traffic control of GLUT4. Nat Rev Mol Cell Biol. 2012;13(6):383-396.

39. Huang S, Czech MP. The GLUT4 glucose transporter. Cell Metab. 2007;5(4):237-252

40. Fort PE, Losiewicz MK, Pennathur S, et al. mTORC1-independent reduction of retinal protein synthesis in type 1 diabetes. Diabetes. 2014;63(9):3077-3090.

41. Yoshihara H, Fukushima T, Hakuno F, et al. Insulin/insulin-like growth factor (IGF) stimulation abrogates an association between a deubiquitinating enzyme USP7 and insulin receptor substrates (IRSs) followed by proteasomal degradation of IRSs. Biochem Biophys Res Commun. 2012;423(1):122-127.

42. Kanazawa T, Taneike I, Akaishi R, et al. Amino acids and insulin control autophagic proteolysis through different signaling pathways in relation to mTOR in isolated rat hepatocytes. J Biol Chem. 2004;279(9): 8452-8459.

43. Müssig K, Häring HU. Insulin signal transduction in normal cells and its role in carcinogenesis. Exp Clin Endocrinol Diabetes. 2010;118(6): 356-359.

44. Gelling RW, Morton GJ, Morrison CD, et al. Insulin action in the brain contributes to glucose lowering during insulin treatment of diabetes. Cell Metab. 2006;3(1):67-73.

45. Morton GJ, Schwartz MW. The NPY/AgRP neuron and energy homeostasis. Int J Obes Relat Metab Disord. 2001;25 Suppl 5: S56-S62.

46. Muniyappa R, Sowers JR. Role of insulin resistance in endothelial dysfunction. Rev Endocr Metab Disord. 2013;14(1):5-12.

47. Losser MR, Damoisel C, Payen D. Bench-to-bedside review: glucose and stress conditions in the intensive care unit. Crit Care. 2010;14(4): 231.

48. Deane AM, Horowitz M. Dysglycaemia in the critically ill - significance and management. Diabetes Obes Metab. 2013;15(9):792-801.

49. Kopelman TR, O’Neill PJ, Kanneganti SR, Davis KM, Drachman DA. The relationship of plasma glucose and glycosylated hemoglobin $\mathrm{A}_{1 \mathrm{c}}$ levels among nondiabetic trauma patients. J Trauma. 2008;64(1):30-33; discussion 33-34

50. Silverman RA, Pahk R, Carbone M, et al. The relationship of plasma glucose and HbA1c Levels among emergency department patients with no prior history of diabetes mellitus. Acad Emerg Med. 2006;13(7):722-726.

51. Ertorer ME, Haydardedeoglu FE, Erol T, et al. Newly diagnosed hyperglycemia and stress hyperglycemia in a coronary intensive care unit. Diabetes Res Clin Pract. 2010;90(1):8-14.

52. Xiu F, Stanojcic M, Diao L, Jeschke MG. Stress hyperglycemia, insulin treatment, and innate immune cells. Int $J$ Endocrinol. 2014;2014:486403.

53. Marik PE, Bellomo R. Stress hyperglycemia: an essential survival response! Crit Care. 2013;17(2):305.

54. May AK, Kauffmann RM, Collier BR. The place for glycemic control in the surgical patient. Surg Infect (Larchmt). 2011;12(5):405-418.

55. Mukherjee K, Sowards KJ, Brooks SE, Norris PR, Jenkins JM, May AK. Insulin resistance increases before ventilator-associated pneumonia in euglycemic trauma patients. Surgical Infections. 2014;15(6):713-720.

56. Preiser JC, Ichai C, Orban JC, Groeneveld AB. Metabolic response to the stress of critical illness. Br J Anaesth. 2014;113(6):945-954. 
57. Cely CM, Arora P, Quartin AA, Kett DH, Schein RM. Relationship of baseline glucose homeostasis to hyperglycemia during medical critical illness. Chest. 2004;126(3):879-887.

58. Sung J, Bochicchio GV, Joshi M, Bochicchio K, Tracy K, Scalea TM. Admission hyperglycemia is predictive of outcome in critically ill trauma patients. J Trauma. 2005;59(1):80-83.

59. Scalea TM, Bochicchio GV, Bochicchio KM, Johnson SB, Joshi M, Pyle A. Tight glycemic control in critically injured trauma patients. Ann Surg. 2007;246(4):605-610; discussion 610-612.

60. Kerby JD, Griffin RL, MacLennan P, Rue LW 3rd. Stress-induced hyperglycemia, not diabetic hyperglycemia, is associated with higher mortality in trauma. Ann Surg. 2012;256(3):446-452.

61. Egi M, Bellomo R, Stachowski E, French CJ, Hart G. Variability of blood glucose concentration and short-term mortality in critically ill patients. Anesthesiology. 2006;105:244-252.

62. Mowery NT, Gunter OL, Dossett LA, et al. Failure to achieve euglycemia despite aggressive insulin control signals abnormal physiologic response to trauma. J Crit Care. 2011;26(3):295-302.

63. Dortch MJ, Mowery NT, Ozdas A, et al. A computerized insulin infusion titration protocol improves glucose control with less hypoglycemia compared to a manual titration protocol in a trauma intensive care unit. JPEN J Parenter Enteral Nutr. 2008;32(1):18-27.

64. Boord JB, Sharifi M, Greevy RA, et al. Computer-based insulin infusion protocol improves glycemia control over manual protocol. $\mathrm{J} \mathrm{Am} \mathrm{Med}$ Inform Assoc. 2007;14(3):278-287.

65. Egi M, Bellomo R, Stachowski E, et al. The interaction of chronic and acute glycemia with mortality in critically ill patients with diabetes. Crit Care Med. 2011;39(1):105-111.

66. Mowery NT, Carnevale RJ, Gunter OL, et al. Insulin resistance heralds positive cultures after severe injury. Surg Infect (Larchmt). 2009;10(6): 503-509.

67. Mowery NT, Gunter OL, Guillamondegui O, et al. Stress insulin resistance is a marker for mortality in traumatic brain injury. $J$ Trauma. 2009;66(1):145-151; discussion 151-153.

68. Mowery NT, May AK, Collier BC, et al. Glucose metabolism, not obesity, predicts mortality in critically ill surgical patients. Am Surg. 2010;76(12):1377-1383.

69. Kauffmann RM, Hayes RM, Jenkins JM, et al. Provision of balanced nutrition protects against hypoglycemia in the critically ill surgical patient. JPEN J Parenter Enteral Nutr. 2011;35(6):686-694.

70. Kauffmann RM, Hayes RM, Buske BD, et al. Increasing blood glucose variability heralds hypoglycemia in the critically ill. $J$ Surg Res. 2011;170(2):257-264.

71. Mowery NT, Gunter OL, Kauffmann RM, Diaz JJ, Collier BC, May AK. Duration of time on intensive insulin therapy predicts severe hypoglycemia in the surgically critically ill population. World J Surg. 2012;36(2):270-277.

72. Nyenwe EA, Kitabchi AE. Evidence-based management of hyperglycemic emergencies in diabetes mellitus. Diabetes Research and Clinical Practice. 2011;94(3):340-351.

73. Gosmanov AR, Gosmanova E, Dillard-Cannon E. Management of adult diabetic ketoacidosis. DMSO. 2014;:255.

74. Casaer MP, Mesotten D, Hermans G, et al. Early versus late parenteral nutrition in critically ill adults. $N$ Engl $J$ Med. 2011;365(6):506-517.

75. Grey NJ, Perdrizet GA. Reduction of nosocomial infections in the surgical intensive-care unit by strict glycemic control. Endocr Pract. 2004; 10 Suppl 2:46-52.

76. De La Rosa Gdel C, Donado JH, Restrepo AH, et al; Grupo de Investigacion en Cuidado intensivo: GICI-HPTU. Strict glycaemic control in patients hospitalised in a mixed medical and surgical intensive care unit: a randomised clinical trial. Crit Care. 2008;12(5):R120.

77. Arabi YM, Dabbagh OC, Tamim HM, et al. Intensive versus conventional insulin therapy: a randomized controlled trial in medical and surgical critically ill patients. Crit Care Med. 2008;36(12): 3190-3197.

78. Preiser JC, Devos P, Ruiz-Santana S, et al. A prospective randomised multi-centre controlled trial on tight glucose control by intensive insulin therapy in adult intensive care units: the Glucontrol study. Intensive Care Med. 2009;35(10):1738-1748.
79. Finfer S, Chittock DR, Su SY, et al; NICE-SUGAR Study Investigators. Intensive versus conventional glucose control in critically ill patients. N Engl J Med. 2009;360(13):1283-1297.

80. Griesdale DE, de Souza RJ, van Dam RM, et al. Intensive insulin therapy and mortality among critically ill patients: a meta-analysis including NICE-SUGAR study data. CMAJ. 2009;180(8):821-827.

81. Krinsley, J. S., \& Grover, A. Severe hypoglycemia in critically ill patients: Risk factors and outcomes*. Critical Care Medicine. 2007;35(10):2262-2267.

82. Bagshaw SM, Egi M, George C, Bellomo R; Australia New Zealand Intensive Care Society Database Management Committee. Early blood glucose control and mortality in critically ill patients in Australia. Crit Care Med. 2009;37(2):463-470.

83. Bagshaw SM, Bellomo R, Jacka MJ, Egi M, Hart GK, George C; ANZICS CORE Management Committee. The impact of early hypoglycemia and blood glucose variability on outcome in critical illness. Crit Care. 2009;13(3):R91.

84. Van den Berghe G, Wilmer A, Hermans G, et al. Intensive insulin therapy in the medical ICU. N Engl J Med. 2006;354(5):449-461.

85. Jacobi J, Bircher N, Krinsley J, et al. Guidelines for the use of an insulin infusion for the management of hyperglycemia in critically ill patients. Crit Care Med. 2012;40(12):3251-3276.

86. Braithwaite SS. Multiplicative standard deviation for blood glucose. Diabetes Technol Ther. 2014;16(4):195-197.

87. Braithwaite SS, Umpierrez GE, Chase JG. Multiplicative surrogate standard deviation: a group metric for the glycemic variability of individual hospitalized patients. J Diabetes Sci Technol. 2013;7(5):1319-1327.

88. Meyfroidt G, Keenan DM, Wang X, Wouters PJ, Veldhuis JD, Van den Berghe G. Dynamic characteristics of blood glucose time series during the course of critical illness: effects of intensive insulin therapy and relative association with mortality. Crit Care Med. 2010;38(4): 1021-1029.

89. Meynaar IA, Eslami S, Abu-Hanna A, van der Voort P, de Lange DW, de Keizer N. Blood glucose amplitude variability as predictor for mortality in surgical and medical intensive care unit patients: a multicenter cohort study. J Crit Care. 2012;27(2):119-124.

90. Krinsley JS. Glycemic variability and mortality in critically ill patients: the impact of diabetes. J Diabetes Sci Technol. 2009;3(6): 1292-1301.

91. Egi M, Bellomo R. Reducing glycemic variability in intensive care unit patients: a new therapeutic target? J Diabetes Sci Technol. 2009;3(6):1302-1308.

92. Sechterberger MK, Bosman RJ, Oudemans-van Straaten HM, et al. The effect of diabetes mellitus on the association between measures of glycaemic and ICU mortality: a retrospective cohort study. Crit Care. 2013;17(2):R52.

93. Pretty CG, Le Compte AJ, Chase JG, et al. Variability of insulin sensitivity during the first 4 days of critical illness: implications for tight glycemic control. Ann Intensive Care. 2012;2(1):17.

94. Frisch A, Chandra P, Smiley D, et al. Prevalence and clinical outcome of hyperglycemia in the perioperative period in noncardiac surgery. Diabetes Care. 2010;33(8):1783-1788.

95. Latham R, Lancaster AD, Covington JF, Pirolo JS, Thomas CS. The association of diabetes and glucose control with surgical-site infections among cardiothoracic surgery patients. Infect Control Hosp Epidemiol. 2001;22(10):607-612.

96. Ouattara A, Lecomte P, Le Manach Y, et al. Poor intraoperative blood glucose control is associated with a worsened hospital outcome after cardiac surgery in diabetic patients. Anesthesiology. 2005;103(4): 687-694.

97. Vriesendorp TM, Morélis QJ, Devries JH, Legemate DA, Hoekstra JB. Early post-operative glucose levels are an independent risk factor for infection after peripheral vascular surgery. A retrospective study. Eur J Vasc Endovasc Surg. 2004;28(5):520-525.

98. Ramos M, Khalpey Z, Lipsitz S, et al. Relationship of perioperative hyperglycemia and postoperative infections in patients who undergo general and vascular surgery. Trans Meet Am Surg Assoc Am Surg Assoc. 2008;126(4):228-234. 
99. Park C, Huh M, Steadman RH, et al. Extended criteria donor and severe intraoperative glucose variability: association with reoperation for hemorrhage in liver transplantation. Transplant Proc. 2010;42(5): 1738-1743.

100. Kiran RP, Turina M, Hammel J, Fazio V. The clinical significance of an elevated postoperative glucose value in nondiabetic patients after colorectal surgery: evidence for the need for tight glucose control? Ann Surg. 2013;258(4):599-604; discussion 604-605.

101. Cianci P. Consensus Development Conference on diabetic foot wound care: a randomized controlled trial does exist supporting use of adjunctive hyperbaric oxygen therapy. Diabetes Care. 2000;23(6):873-874.

102. McMurray JF Jr. Wound healing with diabetes mellitus. Better glucose control for better wound healing in diabetes. Surg Clin North Am 1984;64(4):769-778.

103. Goodson WH 3rd, Hung TK. Studies of wound healing in experimental diabetes mellitus. J Surg Res. 1977;22(3):221-227.

104. Garg R, Chaudhuri A, Munschauer F, Dandona P. Hyperglycemia, insulin, and acute ischemic stroke: a mechanistic justification for a trial of insulin infusion therapy. Stroke. 2006;37(1):267-273.

105. Furnary AP, Zerr KJ, Grunkemeier GL, Starr A. Continuous intravenous insulin infusion reduces the incidence of deep sternal wound infection in diabetic patients after cardiac surgical procedures. Ann Thorac Surg. 1999;67(2):352-360; discussion 360-362.

106. King JT, Goulet JL, Perkal MF, Rosenthal RA. Glycemic control and infections in patients with diabetes undergoing noncardiac surgery. Ann Surg. 2011;253(1):158-165.

107. Marchant MH, Viens NA, Cook C, Vail TP, Bolognesi MP Jr. The impact of glycemic control and diabetes mellitus on perioperative outcomes after total joint arthroplasty. J Bone Joint Surg Am. 2009;91(7): 1621-1629.

108. Olsen MA, Nepple JJ, Riew KD, et al. Risk factors for surgical site infection following orthopaedic spinal operations. J Bone Joint Surg Am. 2008;90(1):62-69.

109. Wukich DK, McMillen RL, Lowery NJ, Frykberg RG. Surgical site infections after foot and ankle surgery: a comparison of patients with and without diabetes. Diabetes Care. 2011;34(10):2211-2213.

110. Smiley DD, Umpierrez GE. Perioperative glucose control in the diabetic or nondiabetic patient. South Med J. 2006;99(6):580-589; quiz 590-591.

111. Umpierrez GE, Smiley D, Jacobs S, et al. Randomized study of basalbolus insulin therapy in the inpatient management of patients with type 2 diabetes undergoing general surgery (RABBIT 2 surgery). Diabetes Care. 2011;34(2):256-261.

112. Ata A, Lee J, Bestle SL, Desemone J, Stain SC. Postoperative hyperglycemia and surgical site infection in general surgery patients. Arch Surg. 2010;145(9):858-864.

113. Yendamuri S, Fulda GJ, Tinkoff GH. Admission hyperglycemia as a prognostic indicator in trauma. J Trauma. 2003;55(1):33-38

114. Laird AM, Miller PR, Kilgo PD, Meredith JW, Chang MC. Relationship of early hyperglycemia to mortality in trauma patients. J Trauma. 2004;56(5):1058-1062.

115. Kreutziger J, Schlaepfer J, Wenzel V, Constantinescu MA. The role of admission blood glucose in outcome prediction of surviving patients with multiple injuries. J Trauma. 2009;67(4):704-708.

116. Garg R, Hurwitz S, Turchin A, Trivedi A. Hypoglycemia, with or without insulin therapy, is associated with increased mortality among hospitalized patients. Diabetes Care. 2013;36(5):1107-1110.

117. Kagansky N, Levy S, Rimon E, et al. Hypoglycemia as a predictor of mortality in hospitalized elderly patients. Arch Intern Med. 2003; 163(15):1825-1829.

118. Krinsley JS, Grover A. Severe hypoglycemia in critically ill patients: risk factors and outcomes. Crit Care Med. 2007;35(10):2262-2267.
119. Vriesendorp TM, van Santen S, DeVries JH, et al. Predisposing factors for hypoglycemia in the intensive care unit. Crit Care Med. 2006;34(1):96-101.

120. Arabi YM, Tamim HM, Rishu AH. Hypoglycemia with intensive insulin therapy in critically ill patients: predisposing factors and association with mortality. Crit Care Med. 2009;37(9):2536-2544.

121. Krinsley JS. Effect of an intensive glucose management protocol on the mortality of critically ill patients. May Clin Proc. 2004;79(8):992-1000.

122. Mowery NT, Guillamondegui OD, Gunter OL, et al. Severe hypoglycemia while on intensive insulin therapy is not an independent predictor of death after trauma. J Trauma. 2010;68(2):342-347.

123. Dossett LA, Cao H, Mowery NT, Dortch MJ, Morris JM Jr, May AK. Blood glucose variability is associated with mortality in the surgical intensive care unit. Am Surg. 2008;74(8):679-685; discussion 685.

124. Ali NA, O'Brien JM Jr, Dungan K, et al. Glucose variability and mortality in patients with sepsis. Crit Care Med. 2008;36(8):2316-2321.

125. Badawi O, Waite MD, Fuhrman SA, Zuckerman IH. Association between intensive care unit-acquired dysglycemia and in-hospital mortality. Crit Care Med. 2012;40(12):3180-3188.

126. Davidson PC, Steed RD, Bode BW. Glucommander: a computer-directed intravenous insulin system shown to be safe, simple, and effective in 120,618 h of operation. Diabetes Care. 2005;28(10):2418-2423.

127. White NH, Skor D, Santiago JV. Practical closed-loop insulin delivery: a system for the maintenance of overnight euglycemia and the calculation of basal insulin requirements in insulin-dependent diabetics. Annals of Internal Medicine. 1982;97:210-213.

128. Newton CA, Smiley D, Bode BW, et al. A comparison study of continuous insulin infusion protocols in the medical intensive care unit: computer-guided vs. standard column-based algorithms. J Hosp Med. 2010;5(8):432-437.

129. Penning S, Le Compte AJ, Moorhead KT, et al. First pilot trial of the STAR-Liege protocol for tight glycemic control in critically ill patients. Comput Methods Programs Biomed. 2012;108(2):844-859.

130. Fogel SL, Baker CC. Effects of computerized decision support systems on blood glucose regulation in critically ill surgical patients. J Am Coll Surg. 2013;216(4):828-833; discussion 833-835.

131. Van Herpe, T, Mesotten D, Wouters, PJ, et al. LOGIC-insulin algorithm-guided versus nurse-directed blood glucose control during critical illness: the LOGIC-1 single-center, randomized, controlled clinical trial. Diabetes Care. 2013;36(2):188-194.

132. Campion TR Jr, Waitman LR, Lorenzi NM, May AK, Gadd CS. Barriers and facilitators to the use of computer-based intensive insulin therapy. Int J Med Inform. 2011;80(12):863-871.

133. Campion TR, May AK, Waitman LR, Ozdas A, Lorenzi NM, Gadd CS. Characteristics and effects of nurse dosing over-rides on computerbased intensive insulin therapy protocol performance. $\mathrm{J} \mathrm{Am} \mathrm{Med}$ Inform Assoc. 2011;18(3):251-258.

134. Vilar-Compte D, Alvarez de Iturbe I, Martín-Onraet A, et al. Hyperglycemia as a risk factor for surgical site infections in patients undergoing mastectomy. Am J Infect Control. 2008 Apr;36(3):192-198.

135. Jackson RS, Amdur RL, White JC, Macsata RA. Hyperglycemia is associated with increased risk of morbidity and mortality after colectomy for cancer. J Am Coll Surg. 2012 Jan;214(1):68-80.

136. Jämsen E, Nevalainen P, Eskelinen A, et al. Obesity, diabetes, and preoperative hyperglycemia as predictors of periprosthetic joint infection: a single-center analysis of 7181 primary hip and knee replacements for osteoarthritis. J Bone Joint Surg Am. 2012 Jul 18;94(14):e101.

137. Kwon S, Thompson R, Dellinger P, Yanez D, Farrohki E, Flum D. Importance of perioperative glycemic control in general surgery: a report from the Surgical Care and Outcomes Assessment Program. Ann Surg. 2013 Jan;257(1):8-14. 


\section{Publish your work in this journal}

Open Access Surgery is an international, peer-reviewed, open access journal that focuses on all aspects of surgical procedures and interventions. Patient care around the peri-operative period and patient outcomes post surgery are key topics. All grades of surgery from minor cosmetic interventions to major surgical procedures are covered. Novel techniques

Submit your manuscript here: http://www.dovepress.com/open-access-surgery-journal and the utilization of new instruments and materials, including implants and prostheses that optimize outcomes constitute major areas of interest. The manuscript management system is completely online and includes a very quick and fair peer-review system. Visit http://www.dovepress.com/ testimonials.php to read real quotes from published authors. 